\title{
Effects of Prazosin in Hematology Parameters and Lipid Profile in Rats (Rattus Norvegicus)
}

\author{
Dr. Zainab Sajid Mohammed \\ College of Pharmacy / Ahl Al-Bayt University, Iraq \\ *e-mail: zaineb1988@gmail.com
}

\begin{abstract}
Alpha blockers are characterize as one of the most therapies that used for treatment of several condition such as Raynaud's disease, hypertension, scleroderma, and one of the most treatments for treated continuing pelvic pain syndrome-continuing prostatitis and also be used to treat anxiety and panic disorder such as generalized anxiety, posttraumatic stress disorder (Raskind, et al.,2003). This study was conducted at the laboratory of department of biology, faculty of science/university of Kufa , 40 male rats that was used. The present study was conducted to investigate the effect of Prazosin hydrochloride on some organs in male rats (Rattus norvegicus), after administration of prazosin hydrochloride at three doses $(25,50,75) \mathrm{mg} / \mathrm{kg}$ b.wt. for eight-weeks, prazosin revealed significant decreased at $(p<0.05)$ the hemoglobin concentration, red blood cell account, packed cell volume, and erythropoietin hormone but a significant increased at $(P<0.05)$ in the levels of erythrocyte sedimentation rate of the blood, when compred with control group, the levels of HDL showed significant increment at $(P<0.05)$ in group that gives low dose $(50$ and 75$) \mathrm{mg} / \mathrm{kg} \mathrm{b.wt}$. when compared with control, but significant decline at $(P<0.05)$ in the levels of very low density lipoprotein in group that gives low dose of prazosin (25) $\mathrm{mg} / \mathrm{kg} \mathrm{b}$.wt. when equaled with control group, the levels of $L D L$ and VLDL revealed significant decreased at $(P<0.05)$ in groups that gives moderate and high doses.
\end{abstract}

Keywords: Alpha blocker, Prazosin Hydrochloride, Erythropoietin

\author{
Article Information \\ Received: November 20, 2020; Online: December 4, 2020
}

\section{INTRODUCTION}

Prazosin hydrochloride is an alpha blocker work by blocking nerve ending called $\alpha$ blockers. This will relaxes the smooth muscle of the urinary bladder and prostate. Minipress significantly compact shock associated with night distrubance and internationally regarded cruelty of prost traumatic disorder of stress, it is also used to treat benign prostatic hyperplasia $(\mathrm{BPH})$ in men which can be recognized by enlargements of prostate which causes difficulties with urination (Raskind, et al., 2000 and Geracioti, et al., 2001).

Prazosin was discovered by investigation team led by at beginning as potential antihypertensive drug after that it was used to treat several disease such as dropping signs of urinary tracts correlated with preservation of urine and BPH. Piperazine, Prazosin was a composed of quinazoline derived, which differ from other alpha blocker drugs such as tamsulosin hydrochloride that composed of methoxy-benzenesulfonamide (Schulman, 1996).

The logical approach for operative managing of the atrial hypertension of prazosin hydrochloride and it's similarities with a strong vasodilator action on the arterial vascular couch are used generally.

It had many compensations such as dilating both confrontation and capacitance of blood vessels, promising hemodynamics influence, simulated absenteeism of reflux tachycardia preserves of kidney blood flow and glomerulus filtration rate and intact auto regulation of 
noradrenalin because of non-blocked of presynaptic $\alpha$ - adreno-receptors (Manfred, at el., 1996).

Antihypertensive drugs are a many quantity of drugs on the market that can be used to lower the BP. They vary from each other in many respects, and the mechanisms of action by which they lower BP differ from each other as well. There can be classified on the basis of the antihypertensive action in lowering the BP. The chief classes of antihypertensive drugs are alpha-receptor blocking agents, beta-receptor blocking agents, calcium channel blockers, angiotensin converting enzyme inhibitors (acetyl choline esterase inhibitor), angiotensin II receptor antagonists and diuretics (Neal, 2000).

There are antihypertensive drugs that have properties from different classes (e.g. combined alpha- and beta-receptor blockers). The medications in these different classes lower BP by different mechanisms, and there are also some pharmacological differences in the mechanisms of action within the classe (Pool, 2000). Alpha-blocking agents affect BP by blocking $\alpha$-adrenoceptors and can be classified into two types, $\alpha 1$-and $\alpha 2$-adrenoreceptors. $\alpha$ adrenoceptors are present in the brain, kidney, heart and vasculature.

Most alpha-blocking agents affect via $\alpha 1$ adrenoreceptors. These lower BP through the reduction of vascular resistance without significant effects on heart rate, cardiac output or central haemodynamics. Some drugs such as carvedilol have combined alpha- and betablocking properties in blocking both $\beta$ - and $\alpha 1$ adrenoceptors to some extent. Carvedilol is a nonselective beta-blocking agent with additional alpha-blocking properties. Frishman ; and Jorde, (2000).

Prazosin hydrochloride are indicated in the treatment of high blood pressure, can be used alone or in combination with other antihypertensive groups such as diuretics or beta-adrenergic blocking agents (Moffat, at el., 2005). Trazocin, Doxazocin, and Prazosin are a selective alpha-1 receptor blockers that all have similar three $\alpha-1$ receptors subtypes, this distinguished from other blocker Tamsulosin, study has been that alpha ( $\alpha$ la AR) relieve bladder based irritability symptoms, in contrast blockade of the $\alpha-1 b$ - adrenergic receptors leads to orthostatic hypotension; a side effect associated with non-select alpha blockers (Zelefsky and Stephen, 2010).

The kidney is the major excretory organ in the body. The principal function is to filter the blood to remove any potential toxic molecules, metabolic crops for instance creatinine and urea and any extra fluid in order to maintain normal volume of blood (Alpern, et al., 2008). Kidney has two the stage an important title role in reabsorbing water and some important molecules such as electrolytes (sodium and potassium) and proteins (Christensen and Gburek, 2004.(Blood filtration occurs in the nephron, the practical unit of the kidney (Alpern, et al.,2000).

Generally, each kidney has more than one million nephrons. Both nephron consists of tubules and glomerulus where blood filtration occurs. The glomerulus contains a filtration membrane which contains of three coatings: the endothelium, the podocyte's epithelial and the basement membrane (Sherwood, 2008).

The glomerular filtration membrane licenses some blood molecules to pass through in order to reach the tubular system which has four parts: convoluted tubules (proximal, distal) ,loop of henle, and collecting tubules of medulla (Alpern ,et al., 2008).

\section{METHODS}

\section{Preparation of Prazosin Hydrochloride (Miniperss) solution:}

The Prazosin was obtained from (pfizerlab,Germany) at concentration $(5 \mathrm{mg} / \mathrm{kg})$, the Prazosin hydrochloride dose $(25,50,75 \mathrm{mg} / \mathrm{kg})$ were prepared by dissolving (1)g from Prazosin in (10)ml from distill water to make stock solution and different concentration from stock solution were prepared.

\section{Experimental animals:}

40 rats (Rattus norvegicus) of male sex weighing ( 210-290) $\mathrm{g}$, animals were housed in aplastic caged, under standard environment condition( temperature $22-25^{\circ} \mathrm{C}$ and $12 \mathrm{hr}$, lightdark cycle) and allowed access to standard laboratory water and feed. They were divided in to four groups (10) animals for each group. 
Group 1: as a control, animals were treated with $(0.5 \mathrm{ml} / \mathrm{kg})$ of distilled water, give orally for 8 weeks.

Group 2: The animals were treated with $(0.5$ $\mathrm{ml}$ ) of volume dose from prazosin at dose $25 \mathrm{mg} / \mathrm{kg}$ for 8 -weeks, give orally.

Group 3: The animals were treated with $(0.5$ $\mathrm{ml}$ ) of volume dose from prazosin at dose $50 \mathrm{mg} / \mathrm{kg}$ for 8 -weeks, give orally.

Group 4: The animals were treated with $(0.5$ $\mathrm{ml}$ ) of volume dose from prazosin at dose 75 $\mathrm{mg} / \mathrm{kg}$ for 8 weeks, give orally.

Haematological Assessments: The parameters of haematology were performed on EDTA blood by using Ruby ( Abbott, U.S.A.) in "Hematology laboratory of AL-Sadder medical city in Najaf province". Roby in a fully automated hematology analyzer (Mathieleers, et al., 2012).

\section{Determination of erythropoietin:}

We determined erythropoietin in the serum of rats by using erythropoietin kit from Kamya Biomedical company, according to the method of (Powell, 1986).

\section{Assessments of Lipid Profile Activity:}

Assessments of Triglyceride:

The quantitative measurement of triglyceride by using TG kit was supplied by biolabo, France, depending on (Fossati and Prencipe, 1982).

\section{Assessments of Total Cholesterol in Serum:}

The quantitative measurement of total cholesterol by using TG kit was supplied by biolabo, France, (Richmond,1973).

Assessments of High Density LipoproteinCholesterol (HDL Cholesterol):

Determination by using precipitant kit was supplied by biolabo, France, (Tietz, 1999).

\section{Assessments of Serum Low Density Lipoprotein-Cholesterol: \\ Determination it by using of precipitant kit was supplied by biolabo, France, (Tietz, 1999).}

Assessments of Serum Very Low Density Lipoprotein: it was calculated according to method of ,(Tietz, 1999).

Bio-statistical analysis: (Steel and Torrie 1960).

\section{RESULTS}

Effect of Prazosin on some hematological tests $(\mathrm{Hb}, \mathrm{RBC}$, and $\mathrm{WBC})$ :

A results in table (1) showed significant decrease $(p<0.05)$ in $\mathrm{Hb}$ and $\mathrm{RBC}$ but significant rise $(p<0.05)$ in WBCs levels in treated groups with Prazosin when compared with control.

Table (1): Effect of prazosin hydrochloride on $\mathrm{Hb}, \mathrm{RBC}$, and $\mathrm{WBC}$ of male rat treated with Prazosin for 8 weeks.

\begin{tabular}{|c|c|c|c|}
\hline Groups & $\begin{array}{c}\mathrm{Hb} \\
(\mathrm{mg} / \mathrm{dl})\end{array}$ & $\begin{array}{c}\mathrm{RBC} \\
\left(10^{6} / \mathrm{mm}\right. \\
3\end{array}$ & $\begin{array}{c}\mathrm{WBC} \\
\left(10^{3} / \mathrm{mm}\right. \\
3\end{array}$ \\
\hline Control & $\begin{array}{c}14.08 \pm 0.14 \\
0\end{array}$ & $\begin{array}{c}7.14 \pm 0.1 \\
5\end{array}$ & $\begin{array}{c}6.600 .0 \pm \\
244.95\end{array}$ \\
\hline $\begin{array}{c}\text { PZ. } \\
25 \mathrm{mg} / \mathrm{k} \\
\mathrm{g}\end{array}$ & $\begin{array}{c}13.49 \pm 0.19 \\
0\end{array}$ & $5.6 \pm 0.4$ & $\begin{array}{c}10.000 .0 \\
\pm 244.95\end{array}$ \\
\hline $\begin{array}{c}\text { PZ. } \\
50 \mathrm{mg} / \mathrm{k} \\
\mathrm{g}\end{array}$ & $\begin{array}{c}11.99 \pm 0.31 \\
5\end{array}$ & $\begin{array}{c}4.6 \pm \\
0.374\end{array}$ & $\begin{array}{c}13.600 .0 \\
\pm 0.00\end{array}$ \\
\hline $\begin{array}{c}\text { PZ. } \\
75 \mathrm{mg} / \mathrm{k} \\
\mathrm{g}\end{array}$ & $\begin{array}{c}10.24 \pm 0.20 \\
9\end{array}$ & $3.2 \pm 0.20$ & $\begin{array}{l}15.600 .0 \\
\pm 600.00\end{array}$ \\
\hline $\begin{array}{c}\text { L.S.D. } \\
\text { 0.05 }\end{array}$ & 0.427 & 1.649 & 511.615 \\
\hline
\end{tabular}

Values are mean \pm SE. ${ }^{*}$ Significantly different at $p<0.05$

\section{2:Effect of prazosin on some hematological} tests (PCV, RBS, and ESR ):

A results in table (2) showed has a insignificant decline ( $p$ value $<0.05$ ) in packed cell vollume,red blood sugar and erythrocyte sedemintation rate levels in groups of rats that treated with Prazosin hydrochloride at three different doses $(25,50,75) \mathrm{mg} / \mathrm{kg}$ b.wt. for eightweeks in compared with control. 
Table (2): Effect of prazosin on PCV, and ESR in male rats treated with Prazosin.

\begin{tabular}{|l|l|l|}
\hline Groups & PCV\% & ESR(mm) \\
\hline Control & $38.83 \pm 0.48$ & $2.50 \pm 0.22$ \\
\hline PZ. $25 \mathrm{mg} / \mathrm{kg}$ & $35.67 \pm 0.49$ & $22.33 \pm 0.84$ \\
\hline PZ. $50 \mathrm{mg} / \mathrm{kg}$ & $34.33 \pm 0.42$ & $31.00 \pm 0.77$ \\
\hline PZ. $75 \mathrm{mg} / \mathrm{kg}$ & $31.17 \pm 0.48$ & $31.33 \pm 1.71$ \\
\hline L.S.D. 0.05 & 0.935 & 1.773 \\
\hline
\end{tabular}

Values are mean \pm SE. * Significantly different at $\mathrm{p}<0.05$.

\section{3:Effect of prazosin hydrochloride on erythropoietin hormones:}

The results in figure (1) showed a insignificant decrement ( $p$ value $<0.05$ ) in level of erythropoietin and level of calcitonin in serum with in group treated with Prazosin for 8 weeks when compared with control group, the results show the animals treated with Prazosin at low dose $25 \mathrm{mg} / \mathrm{kg}$ b.wt. insignificant decline at (Pvalue $<0.05$ ) in (Erythropoietin) when compared with control group but no significant changed when contrast with groups of rats that's give high doses of Prazosin (50, and 75) $\mathrm{mg} / \mathrm{kg}$ b.wt., the animals treated with Prazosin at high doses $50,75 \mathrm{mg} / \mathrm{kg}$ b.wt. for each extract for 8 weeks showed significant decrement $(p$ value $<0.05$ ) in (Erythropoietin) levels when compared with control group.

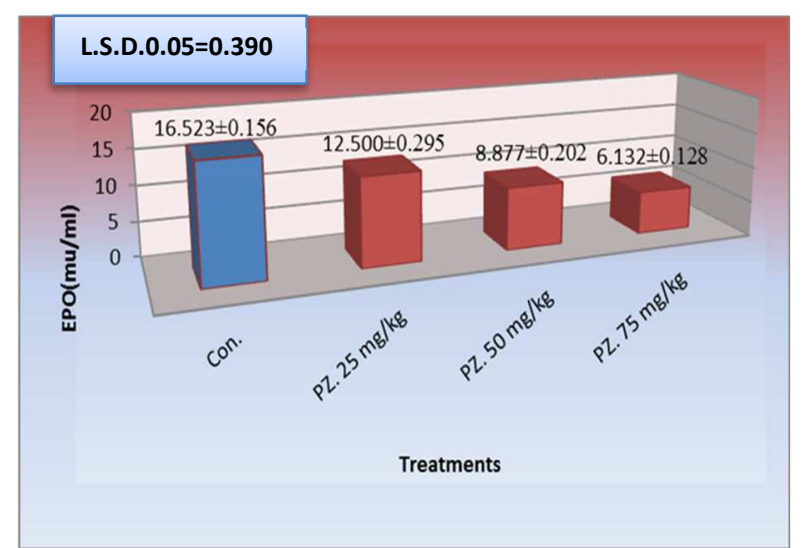

Figure (1): Effect of prazosin at in the serum levels Erythropoietin in male rats.Values are mean \pm SE. *Significantly different at $p<0.05$.

\section{4:Infleunce of prazosin hydrochloride on lipid profile:}

A results in table (3) showed has no insignificant changes $(\mathrm{P}$ value $>0.05)$ cholesterol in group that give low dose $25 \mathrm{mg} / \mathrm{kg}$ b.wt. when compared with control group, but significant decrement at $(\mathrm{P}$ value $<0.05)$ in groups that gives high doses $(50$ and 75$) \mathrm{mg} / \mathrm{kg}$ b.wt., the levels of Triglyceride showed insignificant decresesed at $(\mathrm{P}$ value $<0.05)$ in group that gives low dose (25) $\mathrm{mg} / \mathrm{kg}$ b.wt. when compared with control, but no insignificant change when compared with another group that gives high doses (50 and $75) \mathrm{mg} / \mathrm{kg}$ b.wt., the levels of Triglyceride showed insignificant decresesed at (P value $<0.05)$ in group that gives low dose $(50$ and 75$) \mathrm{mg} / \mathrm{kg}$ b.wt. when compared with control.

The levels of high density lipoprotein revealed a insignificant increased at ( $P$ value $>0.05$ ) in the group that gives low dose (25) $\mathrm{mg} / \mathrm{kg}$ b.wt. when compared with control group, but no significant change when compared with another group that gives high doses (50 and 75$) \mathrm{mg} / \mathrm{kg}$ b.wt.the levels of HDLshowed significant increment at (P value $>0.05)$ in group that gives low dose (50 and 75$) \mathrm{mg} / \mathrm{kg}$ b.wt. when compared with control, the levels of low density lipoprotein revealed no significant change at (p value $=0.05)$, but insignificant decline at $(P$ value $<0.05)$ in the levels of very low density lipoprotein in group that gives low dose of prazosin $(25) \mathrm{mg} / \mathrm{kg}$ b.wt.when equaled with control group, the levels of LDL and VLDL revealed insignificant decreased at $(\mathrm{P}$ value $<0.05)$ in groups that gives high doses $(50$ and 75$) \mathrm{mg} / \mathrm{kg} \mathrm{b.wt}$.

Table (3): Effect of prazosin on lipid profile in male rats treated with Prazosin.

\begin{tabular}{|c|c|c|c|c|c|}
\hline $\begin{array}{l}\text { Gro } \\
\text { ups }\end{array}$ & $\begin{array}{l}\text { Chol. } \\
\text { (mm }\end{array}$ & $\begin{array}{l}\text { TG } \\
(\mathrm{mm} \\
\mathrm{ol} / \mathbf{l})\end{array}$ & $\begin{array}{l}\text { HDL } \\
(\mathrm{mm} \\
\mathrm{ol} / \mathrm{l}) \\
\end{array}$ & $\begin{array}{l}\text { LDL } \\
(\mathrm{mm} \\
\text { ol/l) }\end{array}$ & $\begin{array}{l}\text { VLD } \\
\text { L } \\
(\mathrm{mm} \\
\mathrm{ol} / \mathrm{l})\end{array}$ \\
\hline $\begin{array}{l}\text { Con } \\
\text { trol }\end{array}$ & $\begin{array}{l}78.19 \\
4\end{array}$ & $\begin{array}{l}1 \\
\pm 1.61 \\
3\end{array}$ & $\begin{array}{l}41.65 \\
9 \\
\pm 0.98 \\
7\end{array}$ & $\begin{array}{l}38.18 \\
0 \\
\pm 1.01 \\
70\end{array}$ & $\begin{array}{l}19.05 \\
09 \\
\pm 0.34 \\
73\end{array}$ \\
\hline $\begin{array}{l}P Z . \\
25\end{array}$ & 5 & $\begin{array}{l}90.9 \\
3\end{array}$ & $\begin{array}{l}47 . \\
2\end{array}$ & $\begin{array}{l}38.03 \\
6\end{array}$ & $\begin{array}{l}18.31 \\
8\end{array}$ \\
\hline
\end{tabular}




\begin{tabular}{|c|c|c|c|c|c|}
\hline $\begin{array}{l}\text { Gro } \\
\text { ups }\end{array}$ & $\begin{array}{l}\text { Chol. } \\
\text { (mm } \\
\text { ol/l) }\end{array}$ & $\begin{array}{l}\text { TG } \\
(\mathbf{m m} \\
\mathbf{o l} / \mathbf{l})\end{array}$ & $\begin{array}{l}\text { HDL } \\
(\mathrm{mm} \\
\text { ol/l) }\end{array}$ & $\begin{array}{l}\mathrm{LDL} \\
(\mathrm{mm} \\
\mathrm{ol} / \mathrm{l}) \\
\end{array}$ & \begin{tabular}{|l|} 
VLD \\
$\mathrm{L}$ \\
$(\mathrm{mm}$ \\
$\mathrm{ol} / \mathrm{l})$ \\
\end{tabular} \\
\hline $\begin{array}{l}\mathrm{mg} / \\
\mathrm{kg}\end{array}$ & $\begin{array}{l} \pm 1.45 \\
1\end{array}$ & $\begin{array}{l} \pm 1.76 \\
1\end{array}$ & $\begin{array}{l} \pm 1.24 \\
2\end{array}$ & $\mathbf{0}$ & \pm 0.24 \\
\hline $\begin{array}{l}P Z . \\
50 \\
m g / \\
k g\end{array}$ & $\begin{array}{l}60.04 \\
8 \\
\pm 1.26 \\
5 \\
\end{array}$ & $\begin{array}{l}80.00 \\
0 \\
\pm 0.95 \\
8 \\
\end{array}$ & $\begin{array}{l}63.44 \\
5 \\
\pm 1.33 \\
7 \\
\end{array}$ & \begin{tabular}{|l}
27.82 \\
3 \\
\pm 0.61 \\
2 \\
\end{tabular} & \begin{tabular}{|l}
16.39 \\
1 \\
\pm 0.14 \\
0 \\
\end{tabular} \\
\hline $\begin{array}{l}P Z . \\
75 \\
m g / \\
k g\end{array}$ & $\begin{array}{l}51.71 \\
0 \\
\pm 0.48 \\
0\end{array}$ & $\begin{array}{l}* 67.2 \\
3 \pm \\
1.022 \\
57\end{array}$ & $\begin{array}{l}85.25 \\
0 \\
\pm 1.57 \\
7\end{array}$ & $\begin{array}{l}20.47 \\
7 \\
\pm 0.35 \\
3\end{array}$ & \begin{tabular}{|l}
15.22 \\
7 \\
\pm 0.08 \\
6
\end{tabular} \\
\hline $\begin{array}{l}L . S . \\
D . \\
0.05 \\
\end{array}$ & 913 & 2.778 & 2.571 & 1.511 & \begin{tabular}{|l|}
0.406 \\
\end{tabular} \\
\hline
\end{tabular}

Values are mean \pm SE. * Significantly different at $\mathrm{p}<0.05$.

\section{DISCUSSION}

The results that obtain from this study showed, significant decreased $(\mathrm{P}<0.05)$ in $\mathrm{Hb}$ concentration in treated groups with prazosin at three doses $(25,50,75) \mathrm{mg} / \mathrm{kg}$ b.wt. for eightweeks, this results were identical with previous workers they suggested this decline in $\mathrm{Hb}$ concentration due to effect of prazosin at high doses on delta amino levalinic acid dehydrogenase(d-ALADS) that is found in RBC this enzyme is necessary for formation process of $\mathrm{Hb}$ (Makino, et al., 2000), or may be due to effect prazosin on protophyrin that is principle for formation of $\mathrm{Hb}$.

This present study can give explanation the decrement in the red blood cells, and the changed in the size and shape of packed cells, and hemoglobin concentration that results from changed that occur in the hematopoietic system our findings were similar with previous observation mentions, the spleen plays an important role in the development of the component system of blood, especially in the embryonic stages. In the case of man is a component of the blood center in the embryonic stages, strangely rats in the case remains active in the production of red blood cells on the length of the animal's life (Sty and Conway,1985 and Sieff and Williams, 1995).

Some investigators were recorded about (10$15 \%$ ) of erythropoietin formed in the liver
(Kourge and Bendurant,1992). The liver is main source of production this hormones during embryonic stage, and the hepatocyte is responsible for production large amount of this hormones. The histological results of liver of rats that treated with prazosin at high doses revealed degeneration and necrosis in the hepatocytes, the observations of this present study about histological changes due to affect of prazosin on the liver and kidney tissue of rats which led to alteration the erythropoietin level the later responsible for RBCs production, the peritubular interstitial cells of kidney responsible for production about (85-90\%) from erythropoietin of the formed red blood cells in adult human (Lacombe, 1982), That most people who suffer from kidney disease, they affected with anemia.

This present study showed significant decreased at $(\mathrm{P}<0.05)$ in the packed cell volume in the group treated with prazosin at three doses $(25,50,75) \mathrm{mg} / \mathrm{kg}$ b.wt. for 8 weeks in contrast to control, this results may be attributed to the high doses of prazosin that effect on bone marrow and stem cells that responsible for formation red blood cells ( $\mathrm{RBC}$ ), leading to a significant decreased in number of RBC and decreasing in the PCV (Mohammed, et al., 1998).

These observation came to ensure the previous investigation carried out by Ogawa, (1993) was suggested that the production of white blood cells White blood cells originate from pluripotent haemopoietic stem cells, under the influence of various external stimuli (cytokines, matrix proteins, and accessory cells), stem cells develop into haemopoietic progenitor cells of various lineages.

Growth factors that regulate the development of particular populations of white blood cells, the findings of this present study was revealed a significant increment in white blood cells (leucocyte), that attributed to inflammation and degeneration in tissue and aggregation of lymphocyte.

These present study was similar with the results that obtained by Izaguirre, et al., 1994, mentioned the prazosin is also able to reduce the erythropoietin response that occurs in hypoxemic mice when they are intermittently exposed to hypobaria and to reduce the degree of erythrocytosis in polycythemic mice 
previously exposed to hypobaria on continuous exposure, as the result of the prazosin-induced inhibition of EPO production.

In this present study due to administration of antihypertensive therapy with prazosin at three different doses $(25,-50,75) \mathrm{mg} / \mathrm{kg}$ b.wt. for eight-weeks in 40-rats to moderate essential hypertension resulted in significant decreased in total plasma cholesterol and LDL

This study similar to previous work performed by Lehtonen, et al., (1986), and increase in HDL cholesterol levels when compared with control. present study was explained the increase seen in HDL-C levels, the decreased in hepatic lipase activity was partially influenced by prazosin and since hepatic lipase may play a role in uptake oh HDL-C in the liver, this action may be enhanced by $\alpha$-inhibition these investigator concluded that Prazosin may produce changes in lipid and lipoproteins that are favorable to more efficient cholesterol transport to the liver and out of the body.

The results that obtained from this study showed significant increment, $(\mathrm{P}<0.05)$ in the levels of triglyceride, the levels of cholesterol showed significant decreased $(\mathrm{P}<0.05)$ with in groups of rats that treated with prazosin at high doses $(50,75) \mathrm{mg} / \mathrm{kg}$ b.wt. for eight-weeks, this findings of present study were agree with results that obtained by (Stamler, et al.,1989 ; and Ferrari and Weidmann,1990)

From other hand some works Pool, et al.,(1987) were investigated the effect of alphaAdrenergic Blockers on Plasma Lipoproteins investigated and showed that a consistent pattern has emerged in the effect of alphaadrenergic blockers on lipoproteins in clinical trials. I3.17. 18.22- Doxazosin therapy is associated with reductions in levels of triglycerides and total cholesterol and with increases in the levels of HDL cholesterol and the HDL cholesterol/total cholesterol ratio.

Canaris, et al., 2000; and Duntas , 2002 were reported it is well known that alterations in thyroid function result in changes in the composition and transport of lipoproteins; Triglycerol-secretion rate correlated with plasma triglyceride concentration, these data also suggest a direct effect of alpha- or betaadrenergic blockers on TG secretion rate in the liver, a similar study was performed comparing the effects of doxazosin and propranolol on lipoprotein lipase, and plasma lipid in rats (Jansen and Baggen, 1987).

\section{CONCLUSIONS}

From the current study, it can be concluded that

1. Prazosin at high dose has led to increase the free radicals, reduction liver, kidney and cholestasis biomarkers, imperfect hepatic marker enzymes, increase fibrosis severity and dilation the thyroid, hepatic, lung, and kidney cells design.

2. Lung: emphysema and intestinal pneumonia

\section{REFERENCES}

Canaris GJ, Manowitz NR, Mayor G, Ridgway C, (2000). The Colorado thyroid disease prevalence study. Arch Intern Med 160: 526534.

Duntas, LH.( 2002). Thyroid disease and lipids. Thyroid 12: 287-293.

Ferrari, P. and Weidmann, P.(1990). Insulin, insulin sensitivity and hypertension. J, Hyperrens;8:491-500.

Fossati, P. and Prencipe, L. L. (1982). Serum triglycerides determined colorimetrically with an enzyme that produces hydrogen peroxide. Clin. Chem., 28: 2077-2080.

Frishman ,WH and Jorde ,U . (2000) . $\beta$-adrenergic blockers. In: Oparil S \& Weber MA (eds) Hypertension. Companion to Brenner's and Rector's the kidney. W.B. Saunders Company, London, 590-594.

Izaguirre i, V.; Vargas, M.; Len-Velarde, E.;, Huicho, L.; Monge L, C.; Barce, A.C.; Alippi, R.M. and Bozzini, C.E.(1994). Inhibitory effect of an 1-adrenergic antagonist on erythropoiesis in normoxic or hypoxic mice. Int J Clin Lab Res 24:213-216.

Jansen, H. and Baggen, ROA. (1987). Effects ofdoxazosin and propranolol administration on lipoprotein lipases in cholesterol-fed rats. J Cardiovasc Pharmacol 10 (suppl 9), S16.

Kourge, S.T. and Bendrurant, M.C. (1992). The molecular mechanism of erythropoietin action.Eur.J.Biochem.; 10-649-656.

Lacombe, C. (1982).Preitubular are site of erythropoietin synthesis in murine hypoxia kidney.J.Clin Invest.; 81: 620-626.

Lehtonen, A.; Himanen, P.; Saraste, M.; Niittymaki, K. and Marniemi, J. (1986). Double-blind 
comparison of the effects of long-term treatment with doxazosin or atenolol on serum lipoproteins. Br J Clin Pharmacol2 I, 77s.

Makino, O. P.; Tsuta, H. T. and Takata, T. J. (2000). Relationship between blood lead level and urinary lead level in Workers exposed to very low levels workers exposed to very low level of lead. Ind. Health, 38 (1) :95-8 .

Mathie, I.; Lsabel, G; Fadila, S.; and Rick, G.(2012). Abbott a promise for life. Com, Case book; (191).

Moffat, A.C.; Osselton, M.D., and Widdop, B. (2005).Clarkès Analysis of Drugs and Poisons, Pharmaceutical press.

Mohammed, W. S.; Hamam, A. M. and Tohamy, M. M. (1998). Some Reproductive and Blood Parameters of female Rabbit given different dose lead acetate. J. Union Arab Bio. Cairo, A : 389-399.

Neal B, MacMahon, S, and Chapman, N. (2000).Effects of ACE inhibitors, calcium antagonists, and other blood-pressurelowering drugs: results of prospectively designed overviews of randomised trials. Blood Pressure Lowering Treatment Trialists' Collaboration. Lancet.356 (9246):1955-64.

Ogawa, M. (1993). Differentiation and proliferation of hematopoietic stem cells. Blood; 81: 2844-53.

Pool, JL. (1987).Plasma lipid lowering effects of doxazosin, a new selective alpha, adrenergic inhibitor for systemic hypertension. Am J Cardiol 59, 46G.
Pool，JL. (2000). $\alpha$-Adrenoceptor blockers. In: Oparil S and Weber MA (eds) Hypertension: Companion to Brenner's and Rector's the kidney. W.B. Saunders Company, London, 595-599.

Richmond, W. (1973). Preparation and Properties of Cholesterol Oxidase from Nocardia species and its Applications to the Enzymatic Assay of Total Cholesterol in Serum. Clin. Chem., 19:1350-1356.

Stamler ,R.; Stamler, J.; Gosch, FC.; Berkson ,DM.; Dyer, AR. and Hershinow, P.(1989). Initial antihypertensive drug therapy- a comparison of alpha-blocker (prazosin) and diuretic (hydrochlorothiazide). Am J Med 1989;86( 1B):24-25.

Steel, R. O. D. and Torrie, J.I.I. (1960). Principles and produces of statistics. New York: McGraw-Hill Book Company. USA.

Sty, j.R. and Conway, J.J. (1985). The spleen: development and functional evalution, Nucl Med.; 15; 276-298.

Tietz, N.W. (1999).Text book of Clinical Chemistry, 3rd Ed., C.A. Burtis, E.R. Ashwood, W.B. Saunders . 703-1699.

Zelefsky, J.R. and Stephen, A.O. (2010). Garact and Glaucoma In: The Glaucoma book: apractical; evidence basal approach to patient care schav know, P.N. and John, R. (ed.) . 1st (ed.) Springer Sceince and Business media. LLc., Newyork, PP: 889-892. 